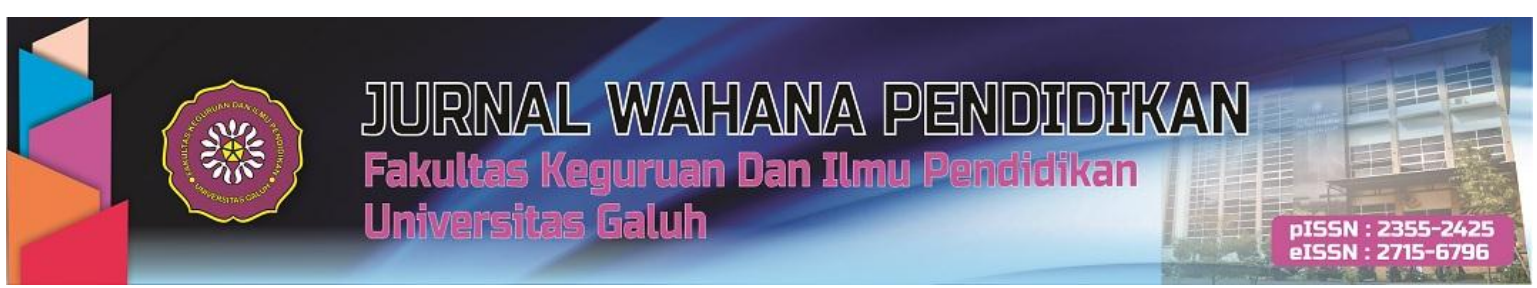

https://jurnal.unigal.ac.id/index.php/jwp

\title{
UPAYA MENINGKATKAN DISIPLIN GURU MELALUI PEMBERIAN REWARD DAN PUNISHMENT DI SDN 3 WONOHARJO TAHUN AJARAN 2018/2019
}

\author{
Suryamah Anshori \\ SDN 3 Wonoharjo Kecamatan Pangandaran Kabupaten Pangandaran Provinsi Jawa Barat \\ Email: suryamahanshori@gmail.com
}

\section{ABSTRACT}

This study aims to improve teachers' discipline in SDN 3 Wonoharjo, Indonesia. The study was conducted through two cycles, each cycle through the stages of planning, implementing actions, observation and reflection. The method used for the data collection was observation and documentation. Based on the data analysis, approximately 1 month, with the concept of 2 times, the implementation of reward and punishment programs has a positive impact on the process of increasing teachers' discipline. Reward and punishment programs are very suitable for teachers. The efforts to improve teachers' discipline through the provision of rewards and punishments by the Principal was on target. The results of the first 10 days were in a score of 115 . This has fulfilled the expectation score of 101. The results of the reflection of the implementation of the other 10 days were in a score of 133. It proved that the teachers' discipline was very good because it approached the maximum score. The results of the questionnaire showed that the score obtained in the first 10 days was 154 which is still far from the maximum score but the teacher had shown changes to be better in terms of their discipline. The results of the questionnaire in the second 10 days showed a very good score of 214 with a maximum score of 240 . This showed that the teacher's discipline was very good.

Keywords: Teacher Discipline, Reward, Punishment.

\section{ABSTRAK}

Penelitian ini bertujuan meningkatkan disiplin guru di SDN 3 Wonoharjo. Penelitian dilaksanakan melalui dua siklus yang masingmasing siklus melalui tahapan perencanaan, pelaksanaan tindakan, observasi dan refleksi. Metode yang digunakan untuk pengumpulan data adalah metode observasi dan metode dokumen. Berdasarkan analisis data, dalam jangka waktu kurang lebih 1 bulan, dengan konsep 2 kali pelaksaan program pemberian reward dan punishment memiliki dampak positif bagi proses peningkatan kedisiplinan Guru pada proses mengajar. Program pemberian reward dan punishment sangat cocok di terapkan pada guru. Upaya meningkatkan kedisiplinan Guru pada proses mengajar melalui pemberian reward dan punishment oleh Kepala Sekolah tepat sasaran. Hasil dari refleksi pelaksanaan 10 hari pertama ini mengahasilkan skor 115 . Hal tersebut sudah memenuhi skor harapan yaitu 101. Hasil refleksi pelaksanaan 10 hari ke 2 ini mengahasilkan skor 133 artinya kedisiplinan guru sudah sangat baik karena mendekati skor maksimal. Adapun hasil angket menunjukkan skor yang di dapat pada 10 hari pertama adalah 154 masih jauh dari skor maksimal namun guru sudah menunjukkan perubahan ke lebih baik dalam hal kedisiplinan. Hasil angket menunjukkan skor yang sangat bagus yakni 214 dengan skor maksimal 240. Hal ini berarti bahwa kedisiplinan guru sudah sangat baik.

Kata Kunci: Disiplin Guru, Reward, Punishment.

Cara sitasi:

Anshori, S. (2020). Upaya Meningkatkan Disiplin Guru Melalui Pemberian Reward Dan Punishment di SDN 3 Wonoharjo Tahun Ajaran 2018/2019. Jurnal Wahana Pendidikan, 7(1), 53-58. 


\section{PENDAHULUAN}

Keberhasilan pembelajaran tergantung dari kemampuan guru. Guru merupakan pendidik profesional dengan tugas utama mendidik, mengajar, membimbing, mengarahkan, melatih, menilai, dan mengevaluasi peserta didik pada tingkatan pendidikan anak usia dini maupun jalur pendidikan formal, pendidikan dasar, dan pendidikan menengah. (Shabir, 2015: 221). Guru professional akan terlihat dari penampilan dalam pelaksanaan dan pengabdian tugas yang ditandai dengan suatu keahlian (skill) baik dalam materi maupun metode pembelajaran yang diberikan.

Keahlian (Skill) yang dimiliki guru profesional diperoleh melalui proses pendidikan dan pelatihan yang diikuti guru yang telah diprogramkan secara khusus. Keahlian tersebut mendapat pengakuan formal yang dinyatakan dalam bentuk sertifikasi, akreditasi, dan lisensi dari pihak yang berwenang (dalam hal ini pemerintah dan organisasi profesi). Keahlian yang dimiliki guru professional ditunjukkan melalui kemampuan untuk menunjukkan otonominya, baik secara pribadi maupun sebagai pemangku profesinya. Sebagaimana diungkapkan Muhlison (2014: 49): "Guru profesional merupakan seseorang yang memiliki keahlian dalam melaksanakan tugas mengajar". Sementara itu Sagala (2009:1) menjelaskan bahwa: "Guru profesional merupakan seseorang yang ahli dalam pekerjaannya, yang mana dengan keahlian yang dimilikinya tersebut guru mampu melaksanakan dan menyelesaikan pekerjaannya secara sungguh-sungguh. Sehingga bukan hanya sebagai pengisi waktu luang atau malah main-main".

Selain dilihat dari keahlian atau skill, seorang guru yang professional juga ditunjukkan melalui tanggungjawabnya dalam hal melaksanakan pengabdiannya dalam kaitannya dengan pembelajaran. Sorang guru profesional harus mampu memikul dan melaksanakan pekerjaan dan tanggung jawabnya kepada peserta didik, masyarakat, orang tua, bangsa, maupun pada agamanya. Hal tersebut karena guru profesional mempunyai tanggung jawab tidak hanya pada diri pribadinya namun juga memiliki tanggungjawab baik secara sosial, tanggungjawab moral, tanggungjawab intelektual, dan tanggungjawab spiritual. Tanggung jawab secara pribadi yakni guru harus mampu mampu memahami pribadi dirinya sendiri. Tanggung jawab sosial tercermin melalui kompetensi dalam kemampuan memahami dirinya sendiri sebagai bagian yang tak terpisahkan dari lingkungan social dimana guru tersebut berada dan bergaul. Guru professional dituntut untuk memiliki kemampuan yang interaktif.

Tanggung jawab intelektual bagi seorang guru professional diwujudkan diantaranya melalui penguasaan berbagai pengetahuan serta keterampilan yang sangat diperlukan untuk menunjang pelaksanaan tugasnya. Tanggung jawab moral dan spiritual dapat diwujudkan melalui penampilan dan perilaku yang agamis. Sikap yang ditunjukkan guru professional tidak menyimpang dari norma agama dam moral yang berlaku di masyarakat.

Kaintanya dengan norma, maka salah satunya adalah yang berhubungan dengan ketepatan waktu dalam hal melaksanakan tugas keseharian dan tanggung jawab yang menjadi profesinya. Waktu tersebut dapat berkaitan dengan masuk, dan keluar kerja, lama dalam melaksanakan proses belajar mengajar dan sebagainya, dimana kesemuanya itu harus ditaati sebagai ciri dari guru yang telah profesional yang memiliki sifat disiplin dalam proses mengajar.

Waktu merupakan modal kerja yang sangat terbatas, sehingga penggunaan waktu harus digunakan secara efektif dan efisien. Banyak kebiasaan yang membuang-buang waktu. Ha tersebut juga menjadi permasalaha di SDN 3 Wonoharjo Kabupaten Pangandaran pada tahun ajaran 2018/2019. Pada saaat jam masuk kegiatan belajar mengajar (KBM) yakni pada pukul 07.00, akan tetapi guru tidak siap dan datang ke kelas terlambat sehingga kegiatan belajar mengajar tidak dapat dilaksanakan secara tepat waktu. Walaupun masih ada beberapa guru yang secara tepat waktu masuk ke kelas, namun itupun tidak secara continue dilaksanakan, sehingga hal ini berdampak negative pada stabilitas sekolah di SDN 3 Wonoharjo Kabupaten. Memang salah satu faktor penyebab nya adalah $70 \%$ jarak tempat tinggal guru dengan sekolah rata-rata di atas $10 \mathrm{~km}$, ditambah transportasi umum kurang. 
Berbagai hal melatar belakangi sulitnya guru menjadi guru professional di SDN 3 Wonoharjo Kabupaten. Diantaranya adanya guru yang tidak memiliki kendaraan pribadi sehingga merasa kesulitan untuk dating tepat waktu ke sekolah ditambah dengan tidak adanya transportasi umum ke SDN 3 Wonoharjo Kabupaten. Hal ini menjadi penyebab terjadinya guru yang dating kesiangan. Hal ini tentu sangat berdampak pada stabilitas sekolah seperti alokasi waktu pelajaran jadi berkurang, siswa berkeliaran di lingkungan sekolah, otomatis prestasi belajar siswa rendah. Guru professional harus mampu merancang pembelajaran efektif dan bermakna, mengorganisasikan pembelajaran, memilih pendekatan pembelajaran yang tepat, menentukan prosedur pembelajaran dan pembentukan kompetensi secara efektif serta menetapkan kriteria keberhasilan, (Ikhsan dan Hadi, 2013: 193).

Sebagai seorang Kepala Sekolah diharapkan mampu mengelola waktu secara efisien, baik untuk tugas-tugas sendiri maupun untuk sekolah secara keseluruhan. Sehingga diharapkan kegiatan proses belajar dan mengajar dapat berjalan secara efektif dan efisien. Oleh karenanya peneliti di sini hendak menggunakan metode pemberian reward (ganjaran) dan punishment (hukuman) kepada guru guru agar bisa disiplin dalam melaksanakan tugasnya. Reward dan punishment merupakan dua bentuk metode yang berfungsi untuk dapat memotivasi seseorang agar mampu melakukan hal yang lebih baik sehingga dapat meningkatkan kinerja dan prestasinya. Kedua metode ini sudah cukup lama dikenal dalam dunia Pendidikan sehingga dalam dunia penidikan kedua metode ini kerap kali digunakan. Namun dalam pengguna kedua metode tersebut selalu terjadi perbedaan pandangan mengenai metode mana yang lebih diprioritaskan antara metode reward atau punishment. Reward (ganjaran) dan punishment (hukuman) merupakan salah satu alat dalamm dunia pendidikan yang berguna untuk dapat meningkatkan usaha dalam memperbaiki atau mempertinggi prestasi dan kinerja yang telah atau akan dicapai oleh seorang guru. Metode reward (ganjaran) merupakan hadiah dan balas jasa bagi seorang guru yang mampu mencapai prestasi dan kinerja dengan baik. (Raihan, 2019:119).

Metode Reward dan punishment mampu mendorong perbuatan seseorang menjadi lebih baik melalui perasaan senang dan bahagia sehingga diharapkan akan melakukan perbuatan baik tersebut secara berulang-ulang. Selain memberikan motivasi, metode reward juga bertujuan agar seseorang agar menjadi lebih giat lagi dalam usahanya untuk memperbaiki dan meningkatkan prestasi yang telah mampu dicapainya.

Sementara metode hukuman (punishment) merupakan suatu cara untuk mengarahkan tingkah laku seseorang agar sesuai dengan ketentuan yang berlaku secara umum. Hukuman diberikan pada saat munculnya tingkah laku yang tidak diharapkan ditampilkan oleh orang yang bersangkutan atau karena tidak memberikan respons dan tidak menampilkan suatu tingkah laku yang telah diharapkan. (Kompri, 2016: 291). Jika reward merupakan bentuk dorongan yang positif; maka punishment merupakan bentuk yang negatif, tetapi pemberian punishment sama-sama bertujuan untuk mendorong ke arah positif. Pemberian metode punishment ini adalah menimbulkan rasa tidak senang kepada seseorang agar jangan berbuat suatu hal yang negative dan tidak sesuai peraturan yang berlaku. Hukuman yang diberikan bersifat pedagogis, yaitu untuk memperbaiki dan mendidik kearah yang lebih baik.

Pada dasarnya kedua metode ini sama-sama dibutuhkan dalam usaha untuk memotivasi seseorang, termasuk dalam memotivasi para guru dalam meningkatkan prestasi dan kinerjanya. Kedua metode ini merupakan langkah usaha yang dilakukan oleh seorang pimpinan dalam memperbaiki kinerja dan produktivitas yang telah ditunjukkan oleh bawahannya; hukuman untuk perbuatan jahat dan ganjaran untuk perbuatan baik. Melihat dari fungsinya tersebut, seolah kedua metode tersebut berlawanan, tetapi pada hakekatnya kedua metode tersebut sama-sama bertujuan agar seseorang menjadi lebih baik, termasuk dalam memotivasi para guru dalam melaksanakan tugas dan tanggungjawabnya. 


\section{METODE PENELITIAN}

Penelitian yang digunakan adalah penelitian tindakan sekolah (School Action Research). Dimana penelitian yang dilakukan bertujuan untuk memecahkan masalah proses pembelajaran di sekolah dalam hal ini SDN 3 Wonoharjo. Penelitian ini menggambarkan bagaimana suatu teknik pembelajaran diterapkan dan bagaimana hasil yang diinginkan dapat dicapai. Penelitian ini mengambil bentuk penelitian tindakan sekolah (PTS) yaitu meningkatkan disiplin guru melalui pemberian reward dan punishment di SDN 3 Wonoharjo berdasarkan atas standar proses, yang terdiri dari 3 siklus dan masing-masing siklus terdiri dari 4 tahap yaitu: (1) Tahap perencanaan program dan tindakan. Rancangan atau rencana awal, peneliti menyusun rumusan masalah, tujuan dan membuat rencana tindakan, termasuk di dalamnya instrumen penelitian dan perangkat pembelajaran yang dilakukan sebelum mengadakan penelitian. (2) Pelaksanaan program dan tindakan. Tindakan dilakukan setelah membuat rancangan yang disusun. Tindakan merupakan bagian yang akan dilakukan dalam Penelitian Tindakan Sekolah dalam penelitian (3) Pengamatan program. Pengamatan dilakukan saat guru melaksanakan kegiatan belajar mengajar di kelas. Data yang dikumpulkan dapat berupa data pengelolaan sekolah. Instrumen yang umum dipakai adalah lembar observasi, dan cacatan lapangan yang dipakai untuk memperoleh data secara objektif yang tidak dapat terekam melalui lembar observasi, misalnya aktivitas peserta didik selama perlakuan berlangsung, reaksi mereka, atau pentunjuk-petunjuk lain yang dapat dipakai sebagai bahan dalam analisis dan untuk keperluan refleksi. (4) Refleksi. Refleksi, peneliti melihat, kemudian mengkaji dan mempertimbangkan hasil atau dampak dari tindakan yang dilakukan berdasarkan lembar pengamatan yang diisi oleh pengamat.

\section{HASIL DAN PEMBAHASAN \\ Deskripsi Data Awal Penelitian}

Penelitian ini dilaksanakan di SDN 3 Wonoharjo dengan subjek penelitian adalah seluruh guru, baik yang sudah menjadi pegawai negeri sipil maupun yang masih tenaga sukwan. Jumlah seluruh guru yang menjadi subyek dalam penelitian adalah adalah 16 orang. Adapun karakteristik kondisi awal guru di SDN 3 Wonoharjo adalah sebagai berikut:

a. $65 \%$ guru datang terlambat dengan alasan rumah yang jauh dan medan ke sekolah yang susah dilalui,

b. $25 \%$ guru datang terlambat dengan alasan hanya mengajar satu mata pelajaran saja,

c. $10 \%$ guru datang terlambat dengan alasan merasa terlalu dibebani dengan tugas lain.

\section{Deskripsi Hasil Tindakan Siklus 1}

Hasil dari refleksi pelaksanaan pemberian reward dan punishment 10 hari pertama ini mengahasilkan skor $115 \mathrm{Hal}$ tersebut sudah memenuhi skor harapan yaitu 101. Hanya saja skor hasil observasi masih terpaut agak banyak dengan skor maksimal. Namun meskipun demikan pelaksanaan pemberian reward dan punishment dalam meningkatkan Kedisiplinan Guru pada proses mengajar pada 10 hari pertama ini berjalan dengan cukup baik. Hal ini terlihat pada hasil observasi yang menunjukan adanya peningkatan Kedisiplinan Guru pada proses mengajar meskipun peningkatan yang terjadi belum tinggi.

Adapun hasil angket juga menunjukkan hasil yang sama dengan hasil observasi, skor yang di dapat paa 10 hari pertama adalah 154 masih jauh dari skor maksimal namun guru sudah menunjukkan perubahan ke lebih baik dalam hal kedisiplinan.

\section{Deskripsi Hasil Tindakan Siklus 2}

Hasil refleksi pelaksanaan pemberian reward dan punishment 10 hari ke 2 ini mengahasilkan skor 133 artinya kedisiplinan guru sudah sanagt baik karena mendekati skor maksimal, selanjutnya hasil angket juga menunjukkan skor yang sangat bagus yakni 214 denagn skor maksimal 240. Hal ini menunjukkan bahwa kedisiplinan guru sdh sangat baik. 
a. Perencanaan

Pada tahap ini, peneliti berusaha merumuskan dan mempersiapkan melakukan tindak lanjut siklus I, yaitu dalam siklus II dilakukan perbaikan. Peneliti dalam hal ini adalah Kepala Sekolah mencari kelebihan dan kekurangan pembinaan kedisiplinan. Kelebihan yang ada pada siklus I dipertahankan pada siklus II, sedangkan mengenai kekurangannya dilakukan perbaikan. Peneliti menyiapkan lembar evaluasi (penilaian), lembar observasi untuk mengetahui peningkatan Kedisiplinan Guru dalam mengajar.

b. Tahap Pelaksanaan

Pelaksanaan Siklus II juga dilaksanakan 1 kali selama seminggu. Langkah tindakan pada siklus II dengan melaksanakan program bembinaan kediplinan berdasarkan pada pengalaman hasil dari siklus I. Dalam tahap ini peneliti melaksanakan metode yang diterapkan berdasarkan Tindakan pada siklus I, perbedaannya adalah pada siklus II dilaksanakan dengan pemberian materi pada pembinaan kedisiplinan yang lebih detail lagi.

c. Pengamatan

Setelah proses bembinaan kedisiplinan selesai maka dilakukan pengamatan selama seminggu terhadap guru. Pengamatan dilakukan untuk mengetahui bagaimana peningkatan Kedisiplinan Guru dalam proses belajar mengajar. Adapun yang di amati pada siklus 2 sama dengan yang diamati pada siklus 1.

d. Refleksi

Refleksi merupakan kegiatan untuk menganalisis data dan informasi yang dikumpulkan dari penelitian tindakan yang dilaksanakan, sehingga dapat diketahui berhasil atau tidaknya tindakan dan perlakuan yang telah dilaksanakan dengan tujuan yang ditentukan.

Hasil dari refleksi pelaksanaan pemberian reward dan punishment 10 hari pertama ini mengahasilkan skor $115 \mathrm{Hal}$ tersebut sudah memenuhi skor harapan yaitu 101. Hanya saja skor hasil observasi masih terpaut agak banyak dengan skor maksimal. Namun meskipun demikan pelaksanaan pemberian reward dan punishment dalam meningkatkan Kedisiplinan Guru pada proses mengajar pada 10 hari pertama ini berjalan dengan cukup baik. Hal ini terlihat pada hasil observasi yang menunjukan adanya peningkatan Kedisiplinan Guru pada proses mengajar meskipun peningkatan yang terjadi belum tinggi.

Adapun hasil angket juga menunjukkan hasil yang sama dengan hasil observasi, skor yang di dapat paa 10 hari pertama adalah 154 masih jauh dari skor maksimal namun guru sudah menunjukkan perubahan ke lebih baik dalam hal kedisiplinan.

Hasil refleksi pelaksanaan pemberian reward dan punishment 10 hari ke 2 ini mengahasilkan skor 133 artinya kedisiplinan guru sudah sanagt baik karena mendekati skor maksimal, selanjutnya hasil angket juga menunjukkan skor yang sangat bagus yakni 214 denagn skor maksimal 240. Hal ini menunjukkan bahwa kedisiplinan guru sdh sangat baik.

\section{KESIMPULAN}

Hasil penelitian menunjukkan bahwa upaya untuk meningkatkatkan disiplin guru melalui reward dan punishment di SDN 3 Wonoharjo Tahun 2018 dapat kondusif dan berjalan dengan lancar. Dalam jangka waktu kurang lebih 1 bulan, dengan konsep 2 kali pelaksaan program pemberian reward dan punishment berdampak positif bagi proses peningkatan Kedisiplinan Guru Pada proses mengajar. Program pemberian reward dan punishment seperti ini sangat cocok sekali di terapkan pada guru. Dengan demikian Upaya Meningkatkan Kedisiplinan Guru Pada proses mengajar Melalui pemberian reward dan punishment Oleh Kepala Sekolah SDN 3 Wonoharjo tepat sasaran. Hasil dari refleksi pelaksanaan pemberian reward dan punishment 10 hari pertama ini mengahasilkan skor 115 Hal tersebut sudah memenuhi skor harapan yaitu 101. Hasil refleksi pelaksanaan pemberian reward dan punishment 10 hari ke 2 ini mengahasilkan skor 133 artinya kedisiplinan guru sudah sanagt baik karena mendekati skor maksimal. Adapun hasil angket juga menunjukkan hasil yang sama dengan hasil observasi, skor yang di dapat pada 10 hari pertama adalah 154 masih jauh dari skor maksimal namun guru sudah menunjukkan perubahan ke lebih 
baik dalam hal kedisiplinan. Hasil angket juga menunjukkan skor yang sangat bagus yakni 214 dengan skor maksimal 240. Hal ini menunjukkan bahwa kedisiplinan guru sdh sangat baik.

\section{REKOMENDASI}

Bagi guru dengan meningkatkan kedisiplinan pada proses mengajar sudah tentu akan membawa dampak positif baik bagi diri guru sendiri dan juga bagi para siswa. Bagi Kepala Sekolah teruslah mencari dan menerapkan program-program yang pas dan cocok untuk memperbaiki kualitas pengajar di sekolah. Hal ini akan menunjang sekali pada tercapainya tujuan pembelajaran.

\section{UCAPAN TERIMAKASIH}

Menyatakan ucapan terimakasih kepada pihak-pihak yang telah membantu dalam kegiatan penelitian yang dilakukan. Pihak-pihak tersebut, misalnya lembaga atau perorangan yang telah memberikan beasiswa, sponsor, dana penelitian, sarana dan prasarana penelitian. Nama orang yang membantu dalam penelitian harus ditulis lengkap dengan gelar yang dimilikinya.

\section{DAFTAR PUSTAKA}

Ikhsan, K. N., \& Hadi, S. (2018). Implementasi dan pengembangan kurikulum 2013. Jurnal Edukasi (Ekonomi, Pendidikan dan Akuntansi), 6(1), 193-202.

Kompri. (2016). Motivasi Pembelajaran Perspektif Guru dan Siswa, Cet. 2. Bandung: Remaja Rosdakarya.

Muhlison, M. (2014). GURU PROFESIONAL (Sebuah Karakteristik Guru Ideal Dalam Pendidikan Islam). Darul Ilmi, 2(2).

Raihan, R. (2019). Penerapan Reward dan Punishment dalam Peningkatan Prestasi Belajar Pendidikan Agama Islam Terhadap Siswa SMA di Kabupaten Pidie. DAYAH: Journal of Islamic Education, 2(1), 115-130

Shabir, M. (2015). Kedudukan guru sebagai pendidik:(tugas dan tanggung jawab, hak dan kewajiban, dan kompetensi guru). AULADUNA: Jurnal Pendidikan Dasar Islam, 2(2), 221-232.

Sagala, S. (2009). Kemampuan Profesional Guru dan Tenaga Kependidikan: Pemberdayaan guru, tenaga kependidikan, dan masyarakat dalam manajemen sekolah. Alfabeta. 